\title{
IUGS: The past four years - 2008-2012
}

Almost four years have passed since I was elected IUGS President for the period 2008-2012. It seems appropriate before concluding my term to report on the main activities undertaken during those four years, especially with regard to what was outlined in my presentation to the IUGS Council in Oslo on August 13, 2008, and my editorial in the 2008 September issue (vol. 31 No. 3) of Episodes.

As then discussed, to develop IUGS activities with limited funds, one of the main activities for the period would be to promote national and international "grassroots" actions within the framework provided by the goals, strategies, and priorities shared by other international organizations, such as UNESCO and the International Council for Science (ICSU). This approach resulted in strong support for the activities of the existing IUGS Commissions, Task Groups, and Initiatives, which work on most of the important aspects of common framework, i.e. standards, geoinformation, geoeducation, and the environment.

To serve the aims just mentioned, different members of the Executive Committee (EC) were asked to work along specific guidelines on the following area: Adhering and Affiliate Members, IUGS Electronic Bulletin (E-Bulletin), International Year of Planet Earth (IYPE), International Geoscience Program (IGCP), and Inactive Members. Task Groups on Adhering and Affiliated Members were created. At the same time these bodies were contacted and their support was requested for promoting multilateral cooperation among them and increasing a productive exchange with other international organizations in matters related to IUGS strategic priorities. For the last four years the Task Groups on Adhering and Affiliate members have been working along those directions. Input on all activities being developed was sought from the IUGS National Committees and Affiliate Organizations through several letters sent by the IUGS President throughout these years; through three editorials published in Episodes (vol. 31 No. 3, vol. 32 No. 3; vol. 33, No. 3); through information included in the IUGS E-Bulletin; and through specific invitations to submit proposals for ICSU's Grants Programme and to suggest candidates for some of the international organizations with which IUGS interacts.

During the last four years the IUGS also tried to improve activities and relationships with ICSU, UNESCO, and other geoscientific organizations. Directed to that goal was the IUGS participation in the $29^{\text {th }}$ and $30^{\text {th }}$ General Assemblies of ICSU (2008, 2011). On both occasions, meetings of geo-related organizations under ICSU's umbrella were directed to coordinate geoscientific activities. Additionally, in these meetings and in many other contacts, specific contributions were made to maintain and reinforce IUGS participation in ICSU activities. Among other specific actions directed to that end, three members of IUGS EC were designated to act as liaisons between IUGS and ICSU's Regional Offices for Africa, Asia and the Pacific, and Latin America and the Caribbean. IUGS interaction with other geo-related organizations - the GeoUnions - and ICSU's grants system resulted in several successful joint projects. Further, following the request of some organizations that there be better coordination of the IGC and IUGG General Assemblies, an IUGS-IUGG task group was formed in 2010 to analyze the issue. Further coordination would probably require another modification of IUGS and IGC Statutes.

With regard to UNESCO, an excellent working relationship was maintained during the whole period with the different officers of the Natural Sciences Sector. IUGS actions were mainly focused on reinforcing existing joint initiatives, such as the International Geosciences Program (IGCP), the Geological Applications of Remote Sensing (GARS), and the International Year of Planet Earth (IYPE 2007-2009), but also on opening new avenues for collaboration in initiatives with a focus on geoeducation, environment and geological heritage, sustainable development, transference of knowledge, data management, and promotion of global standards. Thus, the IUGS became actively involved in promoting the Geoparks initiative as member of the Bureau of the Global Geoparks Network, and in UNESCO's Earth Sciences Education Initiative on Africa, with the active participation of the IUGS Commission on Geological Education and some IUGS Affiliated Members, such as the Geological Society of Africa, the Society for Geology Applied to Mineral Deposits and the Commission for the Geological Map of the World, among others. In addition, the same members of the EC who acted as liaison with ICSU's regional offices were designated to perform the same functions with UNESCO's Regional Science Offices for the same regions.

The IUGS also became: an ex-officio member of the One Geology Steering Group and a promoter of this initiative; a participating member of the Group on Earth Observations (GEO); an active promoter of the YES initiative; a promoter of a Task Group on Global Geological Workforce, a group proposed by the American Geological Institute, formally established by IUGS, with the support of UNESCO. IUGS supported the interaction of One Geology with the IUGS Commission on the Management and Application of Geosciences Information, and a close collaboration on geostandards with other IUGS bodies. This IUGS initiative was also linked to the IUGS interest in interacting with geological surveys through organizations such as EuroGeoSurveys, an organization which became affiliated to the IUGS.

The IUGS continued supporting IYPE until its termination in 2010 and looked for ways to capitalize on its successful results thereafter. Thus, the IUGS has become a supporter of an International Geoscience Initiative, sponsored by several 
Affiliated Organizations, along the lines described in an editorial published in Episodes (2011, vol. 34 No. 3).

The IUGS participated actively in two meetings of the IGC Committee. The two organizations collaborated on efforts to introduce coordinated changes to the IGC and the IUGS Statutes, on preparations for the $34^{\text {th }}$ and $35^{\text {th }}$ IGC, and in the organization of the bid process for the $36^{\text {th }}$ IGC in 2020 .

As soon as the new Executive Committee took office in 2008 , it was confronted with two issues that are fundamental for the work and visibility of the IUGS: the Editorial Office of Episodes and the Secretariat. The relocation of the IUGS Secretariat became necessary when the long-standing support to the Trondheim office was terminated at the close of 2009 by the Norwegian National Committee. The IUGS President was involved in finding a new host country for the IUGS Secretariat, which included negotiations with several countries and resulted in the locating the IUGS Secretariat in the United States for the period 2009-2012 and in Beijing, China, for the period 2012-2020, thanks to the generous support of the U.S. National Committee, the United States Geological Survey and the Geological Society and the Ministry of Land and Resources of China.

At the end of 2008 China's editorial responsibility for the journal Episodes came to an end. As a result of actions taken by the IUGS President, the Editorial Office was relocated in Bangalore, India, for the period 2009-2012, thanks to the generous support of the Geological Society of India. During these years Episodes has been published regularly with the usual high standards, and will continue under similar conditions for the next four years under a new memorandum of understanding to be signed between IUGS and the Geological Society of India.

As usual, Episodes published scientific articles as well as information on the activities of IUGS bodies. Information on IUGS and the geosciences was also disseminated through a monthly E-Bulletin and the IUGS website. With the goal to become a meeting ground for the different bodies of the IUGS, the website was modified, a content management system was added, and graphical improvements were made. Whenever possible the IUGS site was linked to the websites of National Committees and Affiliated Organizations.

To improve IUGS recognition of, and appreciation for, outstanding professional geoscientists, the IUGS Scientific Awards of Excellence, the Episodes Best Paper Award, and the Steno Award were added to the existing James Harrison Outstanding Award. Most of the new awards along with the Harrison Award will be presented in a special ceremony at the 34th IGC (Brisbane, August 2012).

The last two years the IUGS saw two important celebrations: the IUGS $50^{\text {th }}$ and the IGCP $40^{\text {th }}$ Anniversaries. For the IUGS $50^{\text {th }}$ Anniversary, several events were organized: a special video on the IUGS was produced for distribution; on 21 February 2011 a celebration was held at UNESCO Headquarters building in Paris, France, featuring guest speakers and the presentation of medals to those who have shaped the IUGS over the years; and a global essay context was organized for early career geoscientists, under the age of 35 years, to express their views on the future of the geological sciences. The best four essays submitted to the contest were published in Episodes (vol. 34, No.2). The winning author will be provided a travel grant to attend the $34^{\text {th }}$ International Geological Congress and will receive an IUGS medal.

To celebrate the $40^{\text {th }}$ Anniversary of the IUGS - UNESCO International Geoscience Programme (IGCP), a conference was held on 22 February 2012, at UNESCO's Headquarters in Paris, France. The forum brought together numerous experts from different parts of the world. Its purpose was to take stock of the achievements and challenges of the International Programme and map the road ahead. As part of the celebration of the 40 years of the IGCP an anniversary book entitled "Tales Set in Stone, 40 Years of the International Geoscience Programme (IGCP)" was published. The book traces the main achievements of this programme of international scientific cooperation at the service of society.

Despite the global economic downturn and its effects on IUGS membership, the careful management of IUGS finances resulted in positive balance for the period 2008-2012 and a significant surplus was added to the existing reserves. In agreement with IUGS Statutes a Finance Committee was established at the end of 2009 , with the primary role to contribute to the improvement IUGS financial operations, to audit IUGS finances, and to present a report to the IUGS Council every four years before the election of a new EC. The Finance Committee, which has been in operation since 2010, submitted a report on IUGS finances and an audit for approval by the Council at the next IGC (Brisbane, August 2012).

For the IUGS to continue to play and expand its role in the service of international geoscience a Strategic Planning Committee (SPC) was established in 2009 to make recommendations on future directions for the next five years. As a result a new Strategic Plan was prepared and submitted for approval of the IUGS Council at the next IGC (Brisbane, August 2012).

Following IUGS Council instructions to the IUGS Executive Committee and IGC Committee, a joint IUGS-IGCC Statutes and Bylaws Committee was formed. As a result of the work undertaken by the Statutes Committee, a new version of the IUGS Statutes was produced and submitted for ratification of the Council at the $34^{\text {th }}$ IGC (Brisbane, August 2012). It is evident, however, that substantial changes are still needed to improve the working structure of our Union, opening the way, perhaps, for more participation of affiliated organizations and some type of permanent management structure.

In summary, as the reader can see, these were four very full years of activity. Personally I am pleased with the progress and hopeful that it sets a strong foundation for the next Executive Committee and for the future of IUGS.

\section{Alberto C. Riccardi \\ IUGS President}

